Article

\title{
Isolation and Purification of Galloyl, Caffeoyl, and Hexahydroxydiphenoyl Esters of Glucoses from Balanophora simaoensis by High-Speed Countercurrent Chromatography and Their Antioxidant Activities In Vitro
}

\author{
Lei Fang ${ }^{1}$, Tian-Tian $\mathrm{He}^{1}{ }^{1}$, Xiao Wang ${ }^{2}$ and Jie Zhou ${ }^{1, *}$ \\ 1 School of Biological Science and Technology, University of Jinan, Jinan 250022, China; fleiv@163.com (L.F.); \\ htiantian222@163.com (T.-T.H.) \\ 2 Shandong Key Laboratory of TCM Quality Control Technology, Shandong Analysis and Test Center, \\ Qilu University of Technology (Shandong Academy of Sciences), Jinan 250014, China; wangx@sdas.org \\ * Correspondence: zhoujie8761@163.com; Tel: +86-531-8973-6799
}

Received: 23 July 2018; Accepted: 10 August 2018; Published: 14 August 2018

check for updates

\begin{abstract}
High-speed counter-current chromatography was used to separate and purify galloyl, caffeoyl, and hexahydroxydiphenoyl esters of glucoses from the aerial parts of the parasitic plant Balanophora simaoensis for the first time using $n$-hexane-ethyl acetate-methanol-water (1:2:1:2, $v / v)$ as the optimum solvent system. Accordingly, 1-O-(E)-caffeoyl-3-O-galloyl- $\beta$-D-glucopyranose (I, $12.5 \mathrm{mg}), \quad$ 1-O-(E)-caffeoyl-3-O-galloyl-4,6-(S)-hexahydroxydiphenoyl- $\beta$-D-glucopyranose (II, $27.2 \mathrm{mg}$ ), and 1-O-(E)-caffeoyl-4,6-(S)-hexahydroxydiphenoyl- $\beta$-D-glucopyranose (III, $52.8 \mathrm{mg}$ ) with $98.0 \%, 98.5 \%$, and $98.7 \%$ purities, respectively, were purified from $210 \mathrm{mg}$ crude extract of B. simaoensis in a one-step separation. The structures of the glucose esters were identified by electrospray ionization mass spectrometry (ESI-MS) and nuclear magnetic resonance spectra (NMR). Their antioxidant activities were evaluated by measuring their inhibition activity on liver microsomal lipid peroxidation induced by the $\mathrm{Fe}^{2+}$-Cys system in vitro. Compounds I-III showed significant antioxidant activities with $\mathrm{IC}_{50}$ values ranging from 2.51 to $6.68 \mu \mathrm{m}$, respectively.
\end{abstract}

Keywords: Balanophora simaoensis; glucose esters; high-speed counter-current chromatography; antioxidant activities

\section{Introduction}

Balanophora simaoensis (Balanophoraceae) indigenous to China is a parasitic plant growing on the roots of various plants and mainly distributed in the Yunnan province, China [1]. In Chinese traditional medicine, $B$. simaoensis is medicinally used as hemostatic, antidote, and antipyretic agents since ancient times [2]. Previous phytochemical investigations of Balanophora species revealed the presence of various types of bioactive components, such as flavanones, phenylpropanoids, lignans, steroids, triterpenes, glucose esters, and ellagitannins [3-8]. The glucose esters possessing galloyl, caffeoyl and hexahydroxydiphenoyl (HHDP) ester moieties exhibited significant antioxidant activities, thus maybe good candidates for further development with antioxidant potential [9]. In order to further study the biochemical properties of glucose esters from B. simaoensis and to evaluate their clinical applications, it is essential to develop an efficient method for the separation of glucose esters.

However, conventional methods for the isolation of these glucose esters are often based on the extensive use of multiple chromatographic steps, which is time-consuming and offered low recoveries of the target products $[8,10]$. High-speed counter-current chromatography 
(HSCCC) is a liquid-liquid partition chromatography, which is capable of eliminating the solid carrier adsorption and offering total recovery of target compounds. Due to the advantages of HSCCC, it has been widely used in the separation and purification of different kinds of natural products [11,12]. To the best of our knowledge, there are few reports on the preparative separation of glucose esters from plants extracts using HSCCC to date. In the present paper, an efficient HSCCC method has been developed for isolation and purification of three glucose esters, 1-O-(E)-caffeoyl-3-O-galloyl- $\beta$-D-glucopyranose (I), 1-O-(E)-caffeoyl-3-O-galloyl-4,6-(S)HHDP- $\beta$-D-glucopyranose (II), and 1-O-(E)-caffeoyl-4,6-(S)-HHDP- $\beta$-D-glucopyranose (III) from a crude sample of $B$. simaoensis (Figure 1). Furthermore, the antioxidant activities of three glucose esters were evaluated by measuring their inhibition activity on liver microsomal lipid peroxidation induced by the $\mathrm{Fe}^{2+}$-Cys system in vitro.
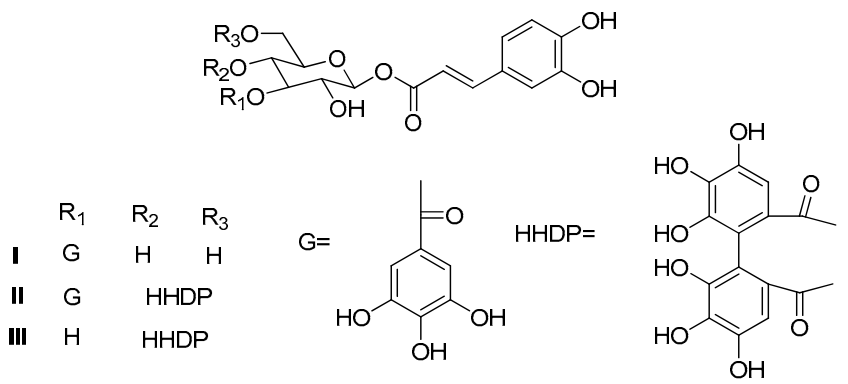

Figure 1. Chemical structures of three glucose esters from B. simaoensis.

\section{Results}

\subsection{Optimization of HPLC Conditions}

Good results were obtained when the mobile phase was acetonitrile (solvent A) and water (solvent B) with the gradient $(0 \mathrm{~min} 15 \% \mathrm{~A} ; 35 \mathrm{~min} 70 \% \mathrm{~A})$. The flow rate and detection wavelength were also investigated. The best results were obtained using $1.0 \mathrm{~mL} / \mathrm{min}$ and $254 \mathrm{~nm}$ as the flow rate and detection wavelength, respectively. The crude extract of $B$. simaoensis was analyzed under the optimized HPLC conditions (Figure 2). As shown in Figure 2, peaks I-III were selected as the target for HSCCC separation in the current work.

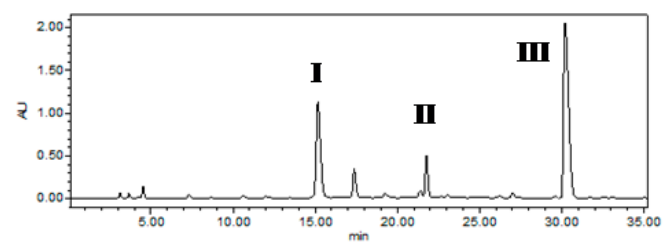

(A)

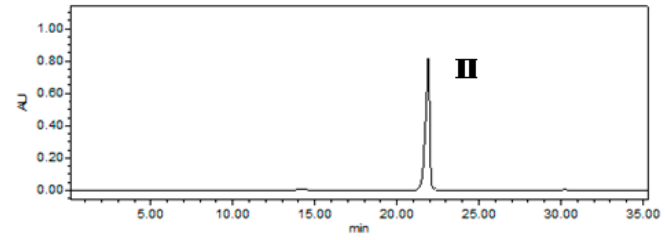

(C)

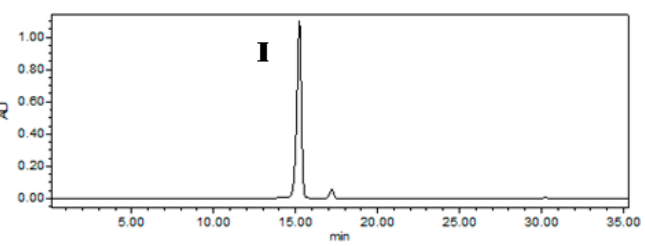

(B)

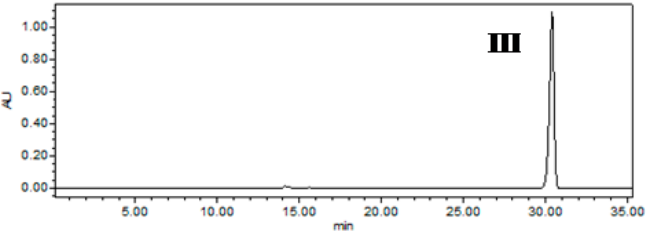

(D)

Figure 2. HPLC chromatogram of the crude extract from B. simaoensis (A) and the three glucose esters purified by HSCCC separation fraction (B-D). 


\subsection{Selection of the Two-Phase Solvent System}

Selection of a suitable two-phase solvent system is the first and critical step in a successful separation using HSCCC. A suitable solvent system should provide ideal partition coefficient $K$ values $(K, 0.5-2)$ and a proper separation factor $(\alpha>1.5)$ of the target compounds [13]. Several two-phase solvent systems were investigated and the $K$ values of three glucose esters were measured in Table 1 .

Table 1. The $K$ values of the target compounds in several solvent system.

\begin{tabular}{cccc}
\hline Solvent System $(\boldsymbol{v} / \boldsymbol{v})$ & \multicolumn{3}{c}{ K } \\
\cline { 2 - 4 } & $\mathbf{I}$ & II & III \\
\hline ethyl acetate- $n$-butanol-water $(5: 2: 6)$ & 9.72 & 15.20 & 18.83 \\
ethyl acetate-ethanol-water (5:1:6) & 4.75 & 11.46 & 19.11 \\
$n$-hexane-ethyl acetate-methanol-water (3:5:3:5) & 0.28 & 0.59 & 1.82 \\
$n$-hexane-ethyl acetate-methanol-water (2:5:2:5) & 0.89 & 1.71 & 3.28 \\
$n$-hexane-ethyl acetate-methanol-water (1:2:1:2) & 0.57 & 1.02 & 2.13 \\
\hline
\end{tabular}

As shown in Table 1 , the $K$ values of three glucose esters were too large in the two-phase solvent systems of ethyl acetate- $n$-butanol-water $(5: 2: 6, v / v)$ and ethyl acetate-ethanol-water $(5: 1: 6, v / v)$, which would cause excessive band broadening and a longer elution time. Then the $n$-hexane-ethyl acetate-methanol-water (HEMWat) system was tested, which has been widely applied to separate various natural products [14]. When the solvent system changed to the HEMWat system (3:5:3:5, 2:5:2:5, 1:2:1:2), the $K$ values of three glucose esters decreased. It can be seen that the $K$ values in the solvent system with the volume ratio of 1:2:1:2 $(v / v)$ were suitable for separation of the target compounds. As shown in Figure 3, good resolution and acceptable separation time could be obtained using $n$-hexane-ethyl acetate-methanol-water $(1: 2: 1: 2, v / v)$ as the two-phase solvent system.

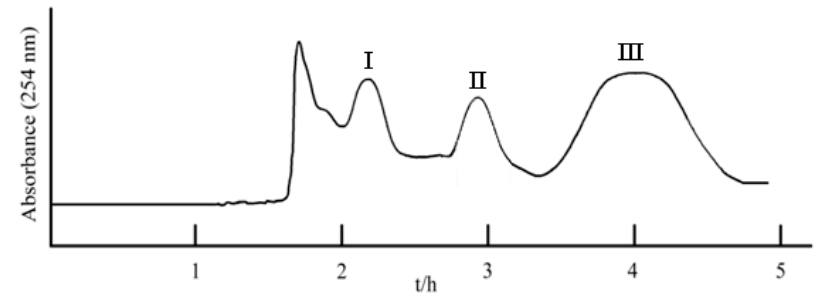

Figure 3. HSCCC chromatogram of the crude sample of B. simaoensis. Solvent system: $n$-Hexane-ethyl acetate-methanol-water (1:2:1:2, v/v); revolution speed: $850 \mathrm{r} / \mathrm{min}$; flow rate: $2.0 \mathrm{~mL} / \mathrm{min}$; sample size: $210 \mathrm{mg}$; UV detection wavelength: $254 \mathrm{~nm}$.

\subsection{HSCCC Separation of Three Glucose Esters}

With the optimized solvent system $n$-hexane-ethyl acetate-methanol-water (1:2:1:2, $v / v)$, the ethyl acetate extract $(210 \mathrm{mg}$ ) of B. simaoensis was successfully separated and purified by HSCCC in one step. As shown in Figure 3, three glucose esters were obtained: 1-O-(E)-caffeoyl-3-O-galloyl- $\beta$-D-glucopyranose $\quad(\mathrm{I}, \quad 12.5 \quad \mathrm{mg}), 1-O-(E)$-caffeoyl-3-O-galloyl-4, 6-(S)-HHDP- $\beta$-D-glucopyranose (II, $27.2 \mathrm{mg}$ ), and 1-O-(E)-caffeoyl-4,6-(S)-HHDP- $\beta$-D-glucopyranose (III, $52.8 \mathrm{mg}$ ). The crude extract and HSCCC fractions were analyzed by HPLC, and the HPLC chromatograms were shown in Figure 2. The purities of three glucose esters were $98.0 \%, 98.5 \%$, and $98.7 \%$ purities, respectively, as determined by HPLC. The retention of the stationary phase was $71.0 \%$, and the separation time was within $5 \mathrm{~h}$ in each separation run. These results demonstrated that HSCCC was a powerful and efficient tool for the preparative separation of glucose esters. 


\subsection{Identification of Separated Compounds}

The structures of three glucose esters were determined by ESI-MS, ${ }^{1} \mathrm{H}-\mathrm{NMR}$, and ${ }^{13} \mathrm{C}-\mathrm{NMR}$ analysis. The results were as follows:

Compound I: ESI-MS m/z: $493[\mathrm{M}-\mathrm{H}]^{-} .{ }^{1} \mathrm{H}-\mathrm{NMR}\left(\mathrm{CD}_{3} \mathrm{OD}-d_{4}, 600 \mathrm{MHz}\right) \delta: 7.65(1 \mathrm{H}, \mathrm{d}, J=15.0 \mathrm{~Hz}$, caf-7), $7.08(1 \mathrm{H}, \mathrm{d}, J=2.4 \mathrm{~Hz}$, caf-2), $7.01(2 \mathrm{H}, \mathrm{s}$, gal-2, 6), $6.92(1 \mathrm{H}, \mathrm{dd}, J=2.4,7.8 \mathrm{~Hz}, \mathrm{caf}-6), 6.74(1 \mathrm{H}, \mathrm{d}$, $J=7.8 \mathrm{~Hz}$, caf-5), $6.31(1 \mathrm{H}, \mathrm{d}, J=15.0 \mathrm{~Hz}$, caf-8), $5.72(1 \mathrm{H}, \mathrm{d}, J=7.8 \mathrm{~Hz}$, glc-1), $5.24(1 \mathrm{H}, \mathrm{t}, J=9.0 \mathrm{~Hz}$, glc-3), $4.48(1 \mathrm{H}, \mathrm{d}, J=12.6 \mathrm{~Hz}$, glc-6a), $4.28(1 \mathrm{H}, \mathrm{d}, J=12.6 \mathrm{~Hz}$, glc-6b), $3.72(1 \mathrm{H}, \mathrm{t}, J=9.0 \mathrm{~Hz}$, glc-4), $3.69\left(1 \mathrm{H}, \mathrm{t}, J=9.6 \mathrm{~Hz}\right.$, glc-2), $3.56\left(1 \mathrm{H}, \mathrm{t}, J=9.4 \mathrm{~Hz}\right.$, glc-5). ${ }^{13} \mathrm{C}-\mathrm{NMR}\left(\mathrm{CD}_{3} \mathrm{OD}-d_{4}, 150 \mathrm{MHz}\right) \delta$ : caffeoyl: 126.5 (C-1), 114.3 (C-2), 145.4 (C-3), 148.5 (C-4), 115.6 (C-5), 122.8 (C-6), 147.6 (C-7), 113.1 (C-8), 166.3 (C-9); galloyl: 119.7 (C-1), 109.5 (C-2, 6), 144.8 (C-3, 5), 138.6 (C-4), 166.5 (C-7); glucose: 94.8 (C-1), 72.5 (C-2), 79.1 (C-3), 69.8 (C-4), 78.2 (C-5), 62.1 (C-6). On comparison with the reported data [8], compound I was identified as 1-O-(E)-caffeoyl-3-O-galloyl- $\beta$-D-glucopyranose.

Compound II: ESI-MS m/z: $795[\mathrm{M}-\mathrm{H}]^{-} .{ }^{1} \mathrm{H}-\mathrm{NMR}\left(\mathrm{CD}_{3} \mathrm{OD}-d_{4}, 600 \mathrm{MHz}\right) \delta: 7.64(1 \mathrm{H}, \mathrm{d}, J=16.0 \mathrm{~Hz}$, caf-7), $7.06(1 \mathrm{H}, \mathrm{d}, J=2.4 \mathrm{~Hz}$, caf-2), $7.03(1 \mathrm{H}, \mathrm{dd}, J=2.4,7.8 \mathrm{~Hz}$, caf-6), $7.02(2 \mathrm{H}, \mathrm{s}$, gal-2, 6), 6.78 $(1 \mathrm{H}, \mathrm{d}, J=7.8 \mathrm{~Hz}$, caf-5), 6.60, 6.45 (each 1H, s, HHDP-3, 3'), $6.32(1 \mathrm{H}, \mathrm{d}, J=16.0 \mathrm{~Hz}$, caf-8), $5.76(1 \mathrm{H}$, d, $J=7.8 \mathrm{~Hz}$, glc-1), $5.42(1 \mathrm{H}, \mathrm{t}, J=9.6 \mathrm{~Hz}$, glc-3), $5.32(1 \mathrm{H}, \mathrm{dd}, J=6.6,13.2 \mathrm{~Hz}, \mathrm{glc}-6 \mathrm{a}), 5.07(1 \mathrm{H}, \mathrm{t}$, $J=9.6 \mathrm{~Hz}$, glc-4), $4.30(1 \mathrm{H}, \mathrm{brdd}, J=6.6,9.6 \mathrm{~Hz}$, glc-5), $3.84(1 \mathrm{H}, \mathrm{t}, J=8.0 \mathrm{~Hz}$, glc-2), $3.84(1 \mathrm{H}, \mathrm{d}$, $J=13.2 \mathrm{~Hz}$, glc-6). ${ }^{13} \mathrm{C}-\mathrm{NMR}\left(\mathrm{CD}_{3} \mathrm{OD}-d_{4}, 150 \mathrm{MHz}\right) \delta$ :caffeoyl:126.6 (C-1), $114.4(\mathrm{C}-2), 145.3(\mathrm{C}-3), 148.5$ (C-4), 115.4 (C-5), 122.7 (C-6), 147.5 (C-7), 113.2 (C-8), 166.0 (C-9); galloyl: 119.6 (C-1), 109.1 (C-2, 6$), 145.1$ (C-3, 5), 138.4 (C-4), 166.3 (C-7); HHDP: 115.3, $115.0\left(\mathrm{C}-1,1^{\prime}\right), 125.2,125.0\left(\mathrm{C}-2,2^{\prime}\right), 106.9,107.1\left(\mathrm{C}-3,3^{\prime}\right)$, 144.4, $144.5\left(\mathrm{C}-4,4^{\prime}\right), 136.2,136.5\left(\mathrm{C}-5,5^{\prime}\right), 143.1,143.4\left(\mathrm{C}-6,6^{\prime}\right), 167.8,168.1\left(\mathrm{C}-7,7^{\prime}\right)$; glucose: $95.1(\mathrm{C}-1)$, 71.4 (C-2), 74.8 (C-3), 70.1 (C-4), 75.2 (C-5), 65.3 (C-6).Compared with the reported data [8], compound II was identified as 1-O-(E)-caffeoyl-3-O-galloyl-4,6-(S)-hexahydroxydiphenoyl- $\beta$-D-glucopyranose.

Compound III: ESI-MS m/z: $643[\mathrm{M}-\mathrm{H}]^{-} .{ }^{1} \mathrm{H}-\mathrm{NMR}\left(\mathrm{CD}_{3} \mathrm{OD}-\mathrm{d}_{4}, 600 \mathrm{MHz}\right) \delta: 7.66(1 \mathrm{H}, \mathrm{d}, J=16.0 \mathrm{~Hz}$, caf-7), $7.04(1 \mathrm{H}, \mathrm{d}, J=2.4 \mathrm{~Hz}$, caf-2), $6.98(1 \mathrm{H}, \mathrm{dd}, J=2.4,8.0 \mathrm{~Hz}$, caf-6), $6.79(1 \mathrm{H}, \mathrm{d}, J=8.0 \mathrm{~Hz}, \mathrm{caf}-5)$, 6.59, 6.48 (each 1H, s, HHDP-3, 3') $6.30(1 \mathrm{H}, \mathrm{d}, J=16.0 \mathrm{~Hz}, \mathrm{caf}-8), 5.69(1 \mathrm{H}, \mathrm{d}, J=8.0 \mathrm{~Hz}$, glc-1), 5.30 $(1 \mathrm{H}, \mathrm{dd}, J=6.0,12.6 \mathrm{~Hz}$, glc-6), $4.86(1 \mathrm{H}, \mathrm{t}, J=9.6 \mathrm{~Hz}, \mathrm{glc}-4), 4.13(1 \mathrm{H}, \mathrm{brdd}, J=6.0,9.6 \mathrm{~Hz}$, glc-5), $3.80\left(1 \mathrm{H}, \mathrm{d}, J=12.6 \mathrm{~Hz}\right.$, glc-6), $3.79\left(1 \mathrm{H}, \mathrm{t}, J=9.6 \mathrm{~Hz}\right.$, glc-3), $3.56\left(1 \mathrm{H}, \mathrm{t}, J=10.0 \mathrm{~Hz}\right.$, glc-2). ${ }^{13} \mathrm{C}-\mathrm{NMR}$ $\left(\mathrm{CD}_{3} \mathrm{OD}-d_{4}, 150 \mathrm{MHz}\right) \delta$ : caffeoyl: 127.7 (C-1), 115.5 (C-2), 146.3 (C-3), 149.5 (C-4), 116.4 (C-5), 123.2 (C-6), 148.5 (C-7), 114.2 (C-8), 166.5 (C-9); HHDP: 115.0, 115.3 (C-1, 1') , 125.3, 125.5 (C-2, 2' ), 106.4, 107.2 $\left(\mathrm{C}-3,3^{\prime}\right), 144.4,144.8\left(\mathrm{C}-4,4^{\prime}\right), 136.3,136.5\left(\mathrm{C}-5,5^{\prime}\right), 143.7,143.8\left(\mathrm{C}-6,6^{\prime}\right), 167.8,168.1\left(\mathrm{C}-7,7^{\prime}\right)$; glucose: 96.1 (C-1), 72.7 (C-2), 74.5 (C-3), 73.1 (C-4), 75.5 (C-5), 64.7 (C-6). According to literature [8], compound III was identified as1-O-(E)-caffeoyl-4,6-(S)-hexahydroxydiphenoyl- $\beta$-D-glucopyranose.

\subsection{Antioxidant Activities of Three Glucose Esters}

The antioxidant activities of three glucose esters were evaluated by measuring their inhibition activity on liver microsomal lipid peroxidation induced by the $\mathrm{Fe}^{2+}-\mathrm{Cys}$ system in vitro. As shown in Table 2, compounds I-III showed significant antioxidant activities with $\mathrm{IC}_{50}$ values ranging from 2.51 to $6.68 \mu \mathrm{m}$, respectively.

Table 2. Antioxidant activities of Compounds I-III.

\begin{tabular}{cc}
\hline Compounds & IC $_{\mathbf{5 0}}$ Values $(\boldsymbol{\mu m})$ \\
\hline I & 6.68 \\
II & 2.51 \\
III & 3.74 \\
Vitamin E & 2.08 \\
\hline
\end{tabular}




\section{Materials and Methods}

\subsection{Apparatus}

The HSCCC instrument employed in the study was a model TBE-300C high-speed countercurrent chromatography apparatus (Tauto Biotech, Shanghai, China) with three multilayer coils connected in series (total volume: $315 \mathrm{~mL}$; I.D.: $1.6 \mathrm{~mm}$ ), which was equipped with a model TBP-5002S constant-flow pump (Tauto Biotech, Shanghai, China), a Model TBD2000 UV detector (Tauto Biotech, Shanghai, China) operating at $254 \mathrm{~nm}$, and a model HW2000 workstation (Tauto Biotech, Shanghai, China). The temperature of the HSCCC column was controlled at $25^{\circ} \mathrm{C}$ using a Model DC-0506 circulatory temperature regulator (Tauto Biotech, Shanghai, China).

The analytical HPLC system consisted of a Waters Empower system (Milford, MA, USA) with a model 600 pump, a model 600 multi-solvent delivery system, a model 996 diode-array detector, and an Empower workstation. The ESI-MS data were obtained by an Agilent 1100/MSG1946 mass spectrometer (Agilent, Santa Clara, CA, USA). The ${ }^{1} \mathrm{H}$ - and ${ }^{13} \mathrm{C}-\mathrm{NMR}$ experiments wereperformed on a Varian $600 \mathrm{MHz}$ NMR spectrometer (Varian, Palo Alto, CA, USA).

\subsection{Reagents and Materials}

The solvents used for the HSCCC separation and antioxidant assay were analytical grade, and were purchased from Tianjing Chemical Factory (Tianjing, China). Acetontrile was HPLC grade and purchased from Siyou Special Reagent Factory (Tianjin, China). The PBS, liver microsomes, and cysteine were bought from Beijing Solarbio Science \& Technology Co., Ltd. (Beijing, China). The $\mathrm{FeSO}_{4}$ and thiobarbituric acid were obtained from Sigma (St. Louis, MO, USA). The whole plants of B. simaoensis were collected in Yunan, China, and identified by Dr. Jia Li (College of Pharmacy, Shandong University of Traditional Chinese Medicine).

\subsection{Preparation of Crude Sample}

The whole plants of $B$. simaoensis $(1.5 \mathrm{~kg}$ ) were powdered and extracted with $\mathrm{MeOH}$ at room temperature. The extract was filtered and concentrated in vacuo to afford the crude extract (210 g). Then, the extract was suspended in water $(500 \mathrm{~mL})$ and extracted by $n$-hexane $(3 \times 500 \mathrm{~mL})$, ethyl acetate $(3 \times 500 \mathrm{~mL})$, and $n$-butanol $(3 \times 500 \mathrm{~mL})$ in sequence. The ethyl acetate extract were evaporated to dryness, yielding $42 \mathrm{~g}$ of ethyl acetate extract for further HSCCC separation.

\subsection{Selection of Two-Phase Solvent System}

The selection of two-phase solvent system was based on the partition coefficient $(K)$ of the three target compounds. The $K$ values were determined by HPLC [15]; approximately 2 mg of crude extract was added to a test tube, and $2 \mathrm{~mL}$ of equilibrated two-phase solvent system was added. The test tube was shaken violently for several minutes to make the sample fully dissolve. Then, an equal volume of the organic and aqueous phases were analyzed by HPLC. The $K$ value was expressed as the peak area of the compound in the upper phase divided by that in the lower phase.

\subsection{HSCCC Separation}

In the present study, the two-phase solvent system of $n$-hexane-ethyl acetate-methanol-water $(1: 2: 1: 2, v / v)$ was used for the HSCCC separation. The solvent system was thoroughly equilibrated in a separation funnel by repeatedly vigorously shaking at room temperature and separated shortly prior to use. The sample solution was prepared by dissolving the dried extract in the mixture solution of lower phase and upper phase $(1: 1, v / v)$ of the solvent system.

The upper phase was firstly pumped to the multiplayer coiled column as the stationary phase. Then, the lower aqueous phase was pumped into the column at a suitable flowrate of $2 \mathrm{~mL} / \mathrm{min}$, while the apparatus was rotated at a speed of $850 \mathrm{rpm}$. After hydrodynamic equilibrium was established, 
the sample solution was injected into the HSCCC and separated with a head-to-tail mode. The effluent of the HSCCC was continuously monitored by a UV detector at $254 \mathrm{~nm}$. The peaks were collected manually according to the elution profile and then analyzed by HPLC. Finally, the retention of the stationary phase was obtained by measuring the ratio of the organic phase to the whole volume in the multilayer-coiled columns.

\subsection{HPLC Analysis of HSCCC Fractions}

The peak fractions from the crude sample and HSCCC separation were analyzed by HPLC equipped with a Inertsil-ODS-SP column $(250 \times 4.6 \mathrm{~mm}, 5 \mu \mathrm{m}$, GL Sciences Inc., Tokyo, Japan $)$ at room temperature. The mobile phase of acetonitrile (A) and water (B), with gradient 0 min $15 \% \mathrm{~A} ; 35 \mathrm{~min}$ $70 \% \mathrm{~A}$, was applied at a flow rate of $1.0 \mathrm{~mL} / \mathrm{min}$. Chroma grams were recorded at $254 \mathrm{~nm}$.

\subsection{Identification of HSCCC Fractions}

The fractions of the target compounds obtained from the HSCCC were determined by MS, ${ }^{1} \mathrm{H}-$ and ${ }^{13} \mathrm{C}$ - NMR spectra. ESI-MS spectra were analyzed by an Agilent 1100/MS-G1946 (Agilent, Santa Clara, CA, USA) mass spectrometer in the negative ionzation mode. The ${ }^{1} \mathrm{H}-$ and ${ }^{13} \mathrm{C}-\mathrm{NMR}$ spectra were obtained on a Varian-600NMR spectrometer (Varian, Palo Alto, CA, USA).

\subsection{In Vitro Antioxidant}

The antioxidant activities of compounds I-III were evaluated by measuring their inhibition activities on liver microsomal lipid peroxidation induced by the $\mathrm{Fe}^{2+}-\mathrm{Cys}$ system in vitro [16]. Vitamin E was used as a positive control. Briefly, $1 \mathrm{mg} / \mathrm{mL}$ microsomal protein, different concentrations of the test compound or vehicle and $0.2 \mu \mathrm{m}$ cysteine in $0.1 \mathrm{M}$ PBS ( $\mathrm{pH} 7.4$ ) were incubated for $15 \mathrm{~min}$ at $37^{\circ} \mathrm{C}, 0.5 \mu \mathrm{m} \mathrm{FeSO}$ was added, mixed, and incubated for $15 \mathrm{~min}$ at $37^{\circ} \mathrm{C}$ again. The reaction was terminated by addition an equal volume of $20 \%$ TFA. The mixture was centrifuged at $3000 \times g \mathrm{rpm}$ for $10 \mathrm{~min}$. The supernatant $(1 \mathrm{~mL})$ was reacted with $0.67 \%(w / v)$ thiobarbituric acid in a boiling $\mathrm{H}_{2} \mathrm{O}$ bath for $10 \mathrm{~min}$. After cooling, the absorbance was read at $532 \mathrm{~nm}$, and the inhibitory rate was calculated. The value of $\mathrm{IC}_{50}$ was calculated by Origin 8.0 Version software (OriginLab, Northampton, MA, USA) from the graph plotting inhibition percentage.

\section{Conclusions}

In this study, an efficient HSCCC method was developed and successfully applied to the separation and purification of glucose esters from the crude extract of B. simaoensis. From $210 \mathrm{mg}$ of the crude sample, three glucose esters with purity all over $98.0 \%$ were preparative separated and showed significant antioxidant activities by measuring their inhibition activity on liver microsomal lipid peroxidation induced by the $\mathrm{Fe}^{2+}-$ Cys system in vitro. The study is of great reference value for preparative separation of glucose esters with high purity from the Balanophora plants, which also demonstrated that HSCCC is a powerful protocol for quick and efficient separation and purification of active compounds from natural products.

Author Contributions: J.Z. and L.F. conceived and designed the experiments; T.-T.H. and L.F. performed the experiments; X.W analyzed the data; L.F. and J.Z. wrote the paper.

Funding: This work was financially supported by National Key Research Project (2017YFC1702702), Shandong Provincial Key Research Project (2017GSF19115, 2018GSF118158), Shandong Provincial Natural Science Foundation (ZR2017MH019), and the Science Foundation of University of Jinan (XKY1608).

Conflicts of Interest: The authors declare no conflicts of interest. 


\section{References}

1. State Administration of Traditional Chinese Medicine. Chinese Herbal Drug; Shanghai Science and Technology Press: Shanghai, China, 1999; p. 620.

2. Hou, Q.Y.; Dai, Z.; Cheng, X.L.; Lin, R.C. Comparative study on chemical components of five species of Balanophora. Chin. J. Pharm. Anal. 2009, 29, 697-701.

3. Tao, J.Y.; Zhao, J.; Zhao, Y.; Cui, Y.M.; Fang, W.S. BACE inhibitory flavanones from Balanophorainvolucrata Hook. f. Fitoterapia 2012, 83, 1386-1390. [CrossRef] [PubMed]

4. Wei, J.C.; Huo, X.K.; Yu, Z.L.; Tian, X.G.; Deng, S.; Sun, C.P.; Feng, L.; Wang, C.; Ma, X.C.; Jia, J.M. Phenolic acids from Balanophorainvolucrata and their bioactivities. Fitoterapia 2017, 67, 129-135. [CrossRef] [PubMed]

5. Luo, B.; Zou, K.; Guo, Z.Y.; Dan, F.J.; Wang, J.Z. Balanoinvolin, a new steroidderivative from Balanophora involucrate. Chem. Nat. Compd. 2009, 45, 371-373. [CrossRef]

6. Hosokawa, A.; Sumino, M.; Nakamura, T.; Yano, S.; Sekine, T.; Ruangrungsi, N.; Watanabe, K.; Ikegami, F. A new lignan from Balanophoraabbreviata and inhibition of lipopolysaccharide (LPS)-induced inducible nitric oxide synthase (iNOS) expression. Chem. Pharm. Bull. 2004, 52, 1265-1267. [CrossRef] [PubMed]

7. Jiang, Z.H.; Tanaka, T.; Iwata, H.; Sakamoto, S.; Hiorse, Y.; Kouno, I. Ellagitannins and Lignan Glycosides from Balanophora japonica (Balanophoraceae). Chem. Pharm. Bull. 2005, 53, 339-341. [CrossRef] [PubMed]

8. Jiang, Z.H.; Hirose, Y.; Iwata, H.; Sakamoto, S.; Tanaka, T.; Kouno, I. Caffeoyl, coumaroyl, galloyl, and hexahydroxydiphenoyl glucoses from Balanophora japonica. Chem. Pharm. Bull. 2001, 49, 887-892. [CrossRef] [PubMed]

9. Ho, S.T.; Tung, Y.T.; Cheng, K.C.; Wu, J.H. Screening, determination and quantification of major antioxidants from Balanophora laxiflora flowers. Food Chem. 2010, 122, 584-588. [CrossRef]

10. Jiang, Z.H.; Wen, X.Y.; Tanaka, T.; Wu, S.Y.; Liu, Z.Q.; Iwata, H.; Hirose, Y.; Wu, S.G.; Kouno, I. Cytotoxic Hydrolyzable Tannins from Balanophora japonica. J. Nat. Prod. 2008, 71, 719-723. [CrossRef] [PubMed]

11. Fang, L.; Liu, Y.Q.; Yang, B.; Wang, X.; Huang, L.Q. Separation of alkaloids from herbs using high-speed counter-current chromatography. J. Sep. Sci. 2011, 34, 2545-2558. [CrossRef] [PubMed]

12. Sutherland, I.A.; Fisher, D. Role of counter-current chromatography in the modern isolation of Chinese herbal medicines. J. Chromatogr. A 2009, 1216, 740-753. [CrossRef] [PubMed]

13. Ito, Y. Golden rules and pitfalls in selecting optimum conditions for high-speed counter-current chromatography. J. Chromatagr. A 2005, 1065, 145-168. [CrossRef]

14. Oka, F.; Oka, H.; Ito, Y. Systematic search for suitable two-phase solvent systems for high-speed counter-current chromatography. J. Chromatogr. A 1991, 538, 99-108. [CrossRef]

15. Jiang, J.J.; Dong, H.J.; Wang, T.; Zhao, R.X.; Mu, Y.; Geng, Y.L.; Zheng, Z.J.; Wang, X. A strategy for preparative separation of 10 lignans from Justicia procumbens L. by high-speed counter-current chromatography. Molecules 2017, 22, 2024. [CrossRef] [PubMed]

16. Dai, S.J.; Mi, Z.M.; Ma, Z.B.; Li, S.; Chen, R.Y.; Yu, D.Q. Bioactive Diels-Alder type adducts from the stem bark of Morus maroura. Planta Med. 2004, 70, 758-763. [CrossRef] [PubMed]

Sample Availability: Samples of three glucose esters are available from the authors.

(C) 2018 by the authors. Licensee MDPI, Basel, Switzerland. This article is an open access article distributed under the terms and conditions of the Creative Commons Attribution (CC BY) license (http://creativecommons.org/licenses/by/4.0/). 